\title{
メチシリン耐性黄色ブドウ球菌の分離頻度と その年次推移に関する検討
}

——検査部からのリポート——

\author{
高 橋 綾 子, 四方田 幸 恵, 町 田哲 男 \\ 福 村 幸 仁, 小林 功, 熊 倉 久 夫* \\ 加 藤 典 弘, 堀 越 徹**田 波洋*** \\ 群馬大学医学部臨床検査医学教室・中央検査部 (主任・部長 : 小林功教授) \\ *群馬大学医学部第二内科学教室 \\ ** 山梨医科大学脳神経外科学教室 \\ ***篠原病院
}

(平成 2 年 10 月 29 日 受付)

要 旨：1977年から1989年までの13年間において群大病院中央検査部で分離された黄色ブドウ球菌の 薬剤耐性菌の発生状況について述べた。

当院における MRSA の発生は1987年は, 分離黄色ブドウ球菌の10\%程度であったが，1988年以降急 増し1989年には分離黄色ブドウ球菌の50\%を越えるに至った。特に外科系の科で分離頻度が高かった。

分離黄色ブドウ球菌の $98 \%$ minocycline（MINO） chroramphenicol（CP）に対し，1989年まで感 受性を示した。これに対し $\beta$-ラクタム剤や，キノロンカルボン酸剤に対する耐性が1987年を境に急增し 1989年では耐性菌の中では 5 剂而性のものが $18 \%$ で最も多かった。

Key words：メチシリン耐性黄色ブドウ球菌（MRSA）

(北関東医学 41 (1) : 219 226, 1991)

\section{はじめに}

臨床分離黄色ブドウ球菌（以下黄色ブ菌）の薬剤 耐性度を示す指標として，これまでメチシリン耐性 黄色ブ菌 methicilline resistant staphylococcus aureus $(\mathrm{MRSA})^{1)}$ の発生頻度が注目されてきた。

最近，他の常用抗生剤に対しても耐性を獲得した 「多剤耐性 MRSA」が増え, これらによる日和見感 染による死亡例が注目される現状にある21.

MRSA の発生頻度は群馬大学医学部附属病院 (以 下群大病院）では1987年まで10 12\%程度と比較的 低く, 当時 $50 \%$ 前後であった他の大規模病院に比 べ3 5)，いわゆる「模範病院」であったともいえる状 呮にあった. また, 当時当院で分離された MRSAの
ほとんどはキノロンカルボン酸剤, minocycline (MINO), chroramphenicol (CP) 等に感受性で あったため, 当時は問題をさほど深刻には考えてい なかった ${ }^{6,7)}$.しかし1988年以降,当院でも MRSA が 急増し, 高度多剤耐性であることが見い出されてき ている.

免疫力の低下した患者が多数入院している大規模 病院における多剤耐性 MRSA の横行は，いわば「強 毒菌」流行にも比すべき事態であり，早急に対策を 講じなければならないと思われる。このような視点 から今回, 当院における MRSA 発生の経過と現状 について分析したので報告することとした。

論文別刷請求先 $\overline{\mathbf{T}} 371$ 前橋市昭和町三丁目39-22 群馬大学医学部臨床検查医学教室 - 中央検査部 


\section{材料と方 法}

1. 過去 13 年間に群大病院中央検査部で患者検体か ら分離した黄色ブ菌を対象とした。

2. 薬剤感受性試験は一濃度ディスク法（昭和）を 用い, 感受性培地は日水製薬の生培地を用いた。接 種菌量は $10^{5} \sim 10^{6} / \mathrm{cm}^{2}$ 分離株が判定基準 0,1 の場 合は「耐性」; 2,3 を示した場合は「感受性」と判 定し感受性株の検出頻度（％）を「薬㣂感受性率」

(「薬剤」が主語になった場合は「有効率」) と呼ぶ こととした。

3. 多剤耐性度の検定法

菌株が，ある薬剤に感受性の場合はコード “ $1 ”$ で，耐性の場合は“ 0 ”で表すと，例えば 3 薬剤X， $\mathrm{Y}, \mathrm{Z}$ に関する「耐性パターン」（注 1 ）は表 1 に示 すような $2^{3}=8$ 組の「 0 と 1 よりなる 3 桁の数字」 で表わされる。

表 1 耐性パターンのコード表示

\begin{tabular}{|c|c|c|c|c|c|}
\hline \multirow[t]{9}{*}{ 薬 荗 } & $\begin{array}{l}\text { 十進法による } \\
\text { コード }\end{array}$ & \multicolumn{4}{|c|}{$\begin{array}{l}\mathrm{X} \text { 二進法によるコード } \\
\mathrm{Y} Z\end{array}$} \\
\hline & 0 & 0 & 0 & 0 & 全 剂 耐 性 \\
\hline & 1 & 1 & 0 & 0 & \\
\hline & 2 & 0 & 0 & 0 & \\
\hline & 3 & 0 & 0 & 1 & \\
\hline & 4 & 1 & 1 & 0 & \\
\hline & 5 & 1 & 0 & 1 & \\
\hline & 6 & 0 & 0 & 1 & \\
\hline & 7 & 1 & 0 & 1 & 全剂感受性 \\
\hline
\end{tabular}

[脚注 1] ある菌株の「薬骫感受性または耐性」を 複数の抗菌剤についてパターン表示したものを「耐 性パターン resistance pattern」と呼ぶ.

これらの「而性パターン」は十進法の整数 $0 \sim 7$ を二進法で表した数列に相当する.

一般には， n剂については2n組の「耐性パターン」 があり,それらは整数 $0 〜\left(2^{\mathrm{n}}-1\right)$ を二進法で表し

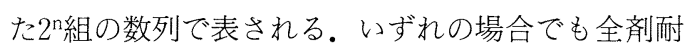
性菌は 0 のみの数列で, 全剤感受性菌は 1 のみの数 列で表される．これらの耐性パターン分析を含む分 離株の疫学分析は, 熊倉, 堀越, 加藤, 町田が開発 したプログラムを用い，N5200-07（NEC）パソコ ンで解析処理した。

4. MRSA の読みかえ
当検査部では methicillin（DMPPC）に対する感 受性を測定していないので, 本稿では類似構造の oxacillin (MPIPC) に耐性 $(>6.25 \mu \mathrm{g} / \mathrm{ml})$ を示し た黄色ブ菌を「MRSA」と呼ぶことにした。

5 . 当大学病院の検査結果デー夕は1988年 7 月以降, 大型ホストコンピューター（ACTS 610），および当 検査部のホストコンピューター (ACOS 410) 配下の 細菌検査室の端末のハードディスクに記憶保存され る.

尚，デー夕は重複分離株を含んでいるので，同一 株の重複分離による統計誤差を除くため重複デー夕 を除いて統計処理した。

本稿では月ごとに，患者検体ごとに最初に分離さ れた黄色ブ菌を統計資料とした。

\section{成績}

1. 黄色ブドウ球菌の薬剤感受性の年度変化

1977年から1988年までの13年間に，本院で分離さ れた黄色ブ菌の常用薬剤に対する感受性率または耐 性菌率（\%）の年次変化を表 2 , 図 1 に示した。

これらの成績で, MINOや CP に対して黄色ブ菌 の98\%が1989年まで感受性を示していることが注目 された。これに対し， $\beta$ ラタム剤やキノロンカルボ ン酸剂に対する耐性黄色ブ菌が1987年を境に一斉 に，しかも急激に増加している(図 1).

一方, 古典的な benzilpenicillin (PCG), erythromycin (EM)，あるいは linchomycin (LCM) など に対しては1977年当時すでに40\%の黄色ブ菌が而性 を示し，1989年では PCG に対しては $80 \%$ が耐性を 示している.これらに対し fosfomycin (FOM) の 有効率は中間的な低下傾向を示している.

なお，ここでは成績を示さなっかたが（本来抗緑 膿菌剂として開発された) carbenicillin (CBPC) や piperacillin (PIPC) も PCG とほぼ同等の有効率低 下を示しており，事実上これらも黄色ブ菌感染症に は無効である。

2. 診療科別 MRSA の発生状況

最近数年間に抢ける MRSA の診療科別（外来, 入院患者別）発生状況を表 3 と図 2 に示した。

ここに見られるように，1985/86年度に打ける MRSA 検出頻度は, 外来, 入院患者検体からそれぞ れ $5.0 \%$ と20\%（全体 $13.7 \%$ ）であった。

これらの值は, 橋本・大久保 ${ }^{8)}$ が1984年当時測定 した（DMPPC 6.25 $\mathrm{g} / \mathrm{ml}$ を境界値とした場合の） 
表 2 黄色ブドウ球菌の薬剤感受性率（\%）の年次変化

\begin{tabular}{|c|c|c|c|c|c|c|c|c|c|c|}
\hline \multirow[t]{2}{*}{ 年 次 } & \multirow[t]{2}{*}{ 株数 } & \multicolumn{4}{|c|}{ ペニシリン系 } & \multicolumn{2}{|r|}{ セ フ } & \multicolumn{2}{|c|}{ 工 厶 系 } & \multirow[b]{2}{*}{ Lmox } \\
\hline & & PcG & $\mathrm{ABPC}$ & MPIPC\# & IPM & CER & $\mathrm{CMZ}$ & СТM & CMX & \\
\hline 1977 & 39 & 56 & 56 & 100 & & 97 & & & & \\
\hline 1978 & 222 & 63 & 70 & 97 & & 99 & & & & \\
\hline 1979 & 229 & 71 & 81 & 92 & & 98 & 95 & & & \\
\hline 1980 & 123 & 48 & 58 & 91 & & 98 & 98 & & & \\
\hline 1981 & 101 & 41 & 55 & 94 & & 95 & 97 & nt & & \\
\hline 1982 & 143 & 31 & 41 & 89 & & 86 & 95 & nt & 90 & \\
\hline 1983 & 232 & 37 & 46 & 96 & & 97 & 99 & nt & 99 & \\
\hline 1984 & 350 & 19 & 30 & 89 & & 86 & 95 & 78 & 94 & 81 \\
\hline $\begin{array}{c}1985 / 8 \sim \\
1986 / 7\end{array}$ & 339 & 31 & 46 & 88 & & 97 & 97 & 95 & 90 & 88 \\
\hline $1987 / 1 \sim 6$ & 208 & 20 & 32 & 90 & 97 & 88 & 98 & 93 & 90 & 91 \\
\hline $1987 / 10 \sim 12$ & 104 & 22 & 34 & 90 & 100 & 94 & 97 & 82 & 81 & 82 \\
\hline 1988 & 343 & 29 & 41 & 66 & 86 & 89 & 84 & 69 & 68 & 68 \\
\hline $1989 / 1 \sim 7$ & 364 & 20 & 37 & 46 & 68 & 69 & 64 & 50 & 51 & 54 \\
\hline
\end{tabular}

\begin{tabular}{|c|c|c|c|c|c|c|c|c|}
\hline \multicolumn{2}{|c|}{$\begin{array}{l}\text { ピリドンカ } \\
\text { ルボン酸剤 }\end{array}$} & \multicolumn{2}{|c|}{ そ } & の & \multicolumn{2}{|l|}{ 他 } & \multicolumn{2}{|c|}{ アミノ配糖体 } \\
\hline NFLX & OFLX & MINO & $\mathrm{CP}$ & EM & LCM & FOM & GM & AMK \\
\hline & & 97 & 64 & 51 & 62 & & & \\
\hline & & 99 & 67 & 44 & 62 & & & \\
\hline & & 99 & 79 & 61 & 71 & & 91 & 97 \\
\hline & & 94 & 48 & 57 & 88 & & 63 & 86 \\
\hline & & 89 & 70 & 40 & 56 & 89 & 54 & 80 \\
\hline & & 68 & $\mathrm{nt}$ & 43 & 65 & 95 & 60 & 78 \\
\hline & & $n t \$$ & nt & 59 & 69 & & 56 & 67 \\
\hline 95 & & nt & nt & 46 & 50 & 77 & 62 & 77 \\
\hline 98 & 99 & 98 & nt & 48 & 69 & 68 & nt & $\mathrm{nt}$ \\
\hline 96 & 99 & 96 & 97 & 51 & 65 & & $\mathrm{nt}$ & $\mathrm{nt}$ \\
\hline 94 & 99 & 95 & 98 & 55 & 64 & & nt & nt \\
\hline 81 & 94 & 98 & 99 & 48 & 55 & 65 & $\mathrm{nt}$ & $\mathrm{nt}$ \\
\hline 64 & 76 & 98 & 99 & 38 & 48 & 51 & (75 & 80) \\
\hline
\end{tabular}

[コメント］1，一濃度ディスク法（昭和）による感受性判定基準 “ 2 ” 以上の感受性を示した分離株の 比率 (\%) を示す.

2. 空欄は当時薬剤未関発。 \#当検查室では MPIPC に対する耐性菌で“MRSA”を代用する。

3. \$nt：感受性検查せず.

a ) MINO，CP は副作用が強いので一時検査を中断した。1987年以降分離された黄色ブ 菌は極めて感受性が高いことが見出された。

b ）アマミノ配糖体はグラム陽性球菌に効果が低いので1987年から検査を中断したが, 黄 色ブ菌については今後検查が必要と考えている.

c ）FOM は黄色ブ菌に対してある程度の抗菌力を示すので MRSA については今後検査 が必要となろう。 
(\%)

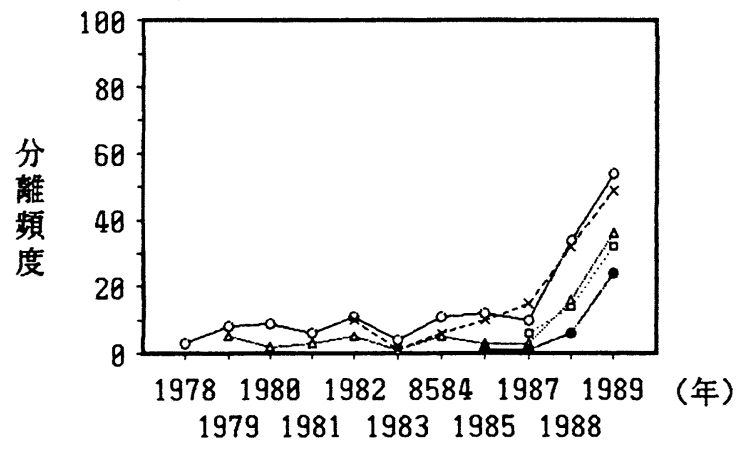

$$
\begin{array}{ll}
\square- & \text { MPIPC } \\
\square \cdots & \text { IMP } \\
\square- & \text { CMZ } \\
\times \cdots & \text { CMX } \\
-- & \text { OFLX }
\end{array}
$$

図 1 而性黄色ブドウ球菌分離頻度
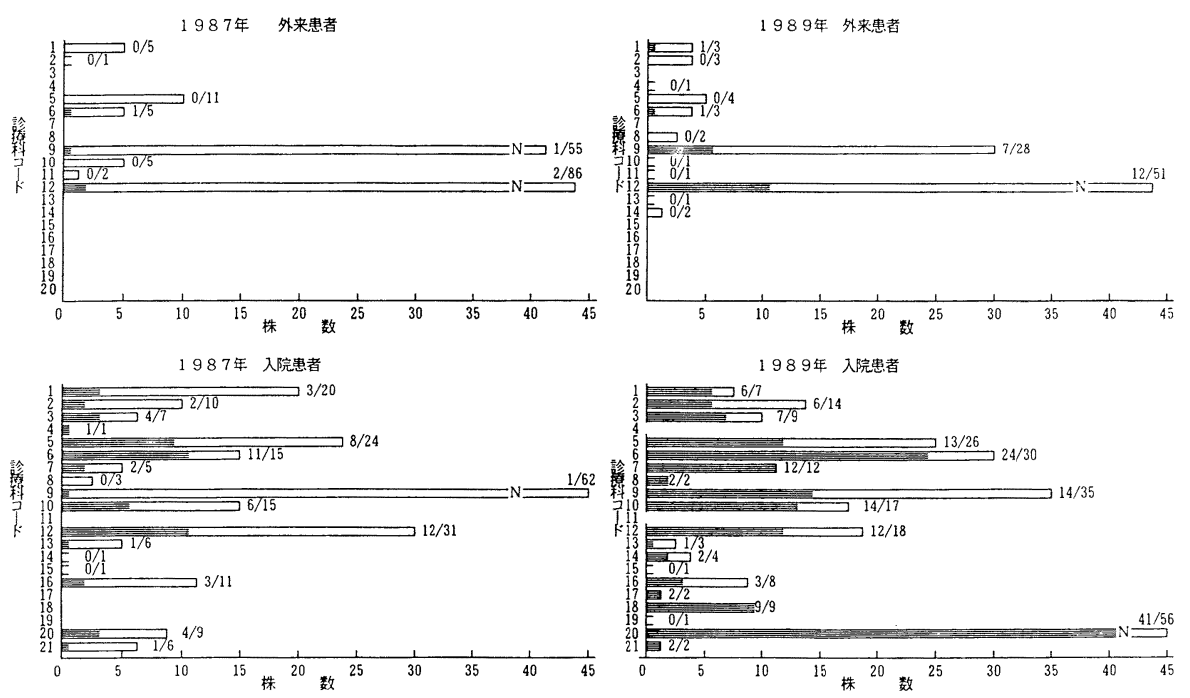

図2 診療科別 MPIPC 耐性菌発生頻度

MRSA 出現頻度, すなうち外来患者から $7.0 \%$, 入 院患者から $21.5 \%$, 全体としては $14.8 \%$ にほほ致 している。

1989年に扔いては入院患者から分離された黄色ブ 菌の $66 \%$ が MRSA であり（表 3)，また主要セフェ 厶剤に対する耐性黄色ブ菌も50\%に達している（表 2 ).

診療科別（表 3 ）にみると，1989年において外来 で最も分離頻度の高かった09, 12 の診療科でも MRSA は25\%をこえていない. しかし入院別では10 株以上の S.aureus が分離された科で，06，07，10， 12，20，では70\%以上が MRSA であり，ほとんど が外科系である.01,03の内科系でも MRSA は70\%
を越えているが，まだ総分離株数は多くないように 思われる。

3. 新薬 Imipenem/cilastatin sodium（IPM）に対 する耐性菌の出現.

当院では1987年10月から IPM の使用が開始され た。当初 IPM は黄色ブ菌のほぼ $100 \%$ に有効であ り，しかも大部分の株についての，ディスク法の阻 止円径から推定された MIC は $0.01 \mu \mathrm{g} / \mathrm{ml}$ という極 めて優れた值を示した。

ところが, 使用開始からわずか 1 年半後の 1989 年 1〜 7 月現在では, 分離株の $30 \%$ がすでに IPM 耐 性を獲得しており，そのほとんどすべては MRSA であった。 
表 $3 \mathrm{MRSA}$ の診療科別 - 年次別発生状況

\begin{tabular}{|c|c|c|c|c|c|c|c|c|}
\hline \multirow{2}{*}{ 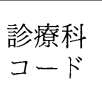 } & 外 & 来 & 患 & 者 & 入 & 院 & 患 & 者 \\
\hline & $1985 / 86$ & 1987 & 1988 & 1989 & $1985 / 86$ & 1987 & 1988 & 1989 \\
\hline 01 & $0 / 2$ & $0 / 5$ & $0 / 5$ & $1 / 3$ & $8 / 16$ & $3 / 20$ & $3 / 11$ & $6 / 7$ \\
\hline 02 & & $0 / 1$ & & $0 / 3$ & $1 / 8$ & $2 / 10$ & $1 / 6$ & $6 / 14$ \\
\hline 03 & & & & & $0 / 5$ & $4 / 7$ & $5 / 9$ & $7 / 9$ \\
\hline 04 & & & $0 / 3$ & $0 / 1$ & $0 / 1$ & $1 / 1$ & $0 / 3$ & \\
\hline 05 & $0 / 7$ & $0 / 11$ & $0 / 5$ & $0 / 4$ & $7 / 25$ & $8 / 24$ & $0 / 23$ & $13 / 26$ \\
\hline 06 & $1 / 4$ & $1 / 5$ & & $1 / 3$ & $2 / 13$ & $11 / 15$ & $20 / 25$ & $24 / 30$ \\
\hline 07 & $0 / 3$ & & & & $5 / 14$ & $2 / 5$ & $6 / 12$ & $12 / 12$ \\
\hline 08 & & & & $0 / 2$ & $1 / 2$ & $0 / 3$ & & $2 / 2$ \\
\hline 09 & $0 / 22$ & $1 / 55$ & $0 / 26$ & $7 / 28$ & $1 / 48$ & $1 / 62$ & $3 / 31$ & $14 / 35$ \\
\hline 10 & $0 / 3$ & $0 / 5$ & & $0 / 1$ & $2 / 14$ & $6 / 15$ & $0 / 5$ & $14 / 17$ \\
\hline 11 & & $0 / 2$ & & $0 / 1$ & & & & \\
\hline 12 & $6 / 93$ & $2 / 86$ & $16 / 55$ & $12 / 51$ & $3 / 23$ & $12 / 31$ & $4 / 15$ & $12 / 18$ \\
\hline 13 & & & & $0 / 1$ & $0 / 5$ & $1 / 6$ & $2 / 3$ & $1 / 3$ \\
\hline 14 & $0 / 1$ & & $0 / 5$ & $0 / 2$ & & $0 / 1$ & $2 / 6$ & $2 / 4$ \\
\hline 15 & & & & & $6 / 14$ & $0 / 1$ & $0 / 1$ & $0 / 1$ \\
\hline 16 & & & & & & $3 / 11$ & $2 / 4$ & $3 / 8$ \\
\hline 17 & $0 / 1$ & & & & & & & $2 / 2$ \\
\hline 18 & & & & & & & $2 / 10$ & $9 / 9$ \\
\hline 19 & & & & & & & $5 / 11$ & $0 / 1$ \\
\hline 20 & & & & & $3 / 12$ & $4 / 9$ & $58 / 62$ & $41 / 56$ \\
\hline 21 & & & & & & $1 / 6$ & $0 / 3$ & $2 / 2$ \\
\hline $\begin{array}{l}\text { 合 計 } \\
(\%)\end{array}$ & $\begin{array}{r}7 / 139 \\
(5.0 \%)\end{array}$ & $\begin{array}{r}4 / 170 \\
(2.4 \%)\end{array}$ & $\begin{array}{c}16 / 99 \\
(16.2 \%)\end{array}$ & $\begin{array}{r}21 / 100 \\
(21.0 \%)\end{array}$ & $\begin{array}{r}40 / 203 \\
(19.7 \%)\end{array}$ & $\begin{array}{r}59 / 227 \\
(26.0 \%)\end{array}$ & $\begin{array}{l}103 / 240 \\
(54.2 \%)\end{array}$ & $\begin{array}{l}170 / 256 \\
(66.4 \%)\end{array}$ \\
\hline
\end{tabular}

[注］本稿では MPIPC 耐性ブ菌を MRSA と読み替える。空欄は分離ブ菌無しを示す.

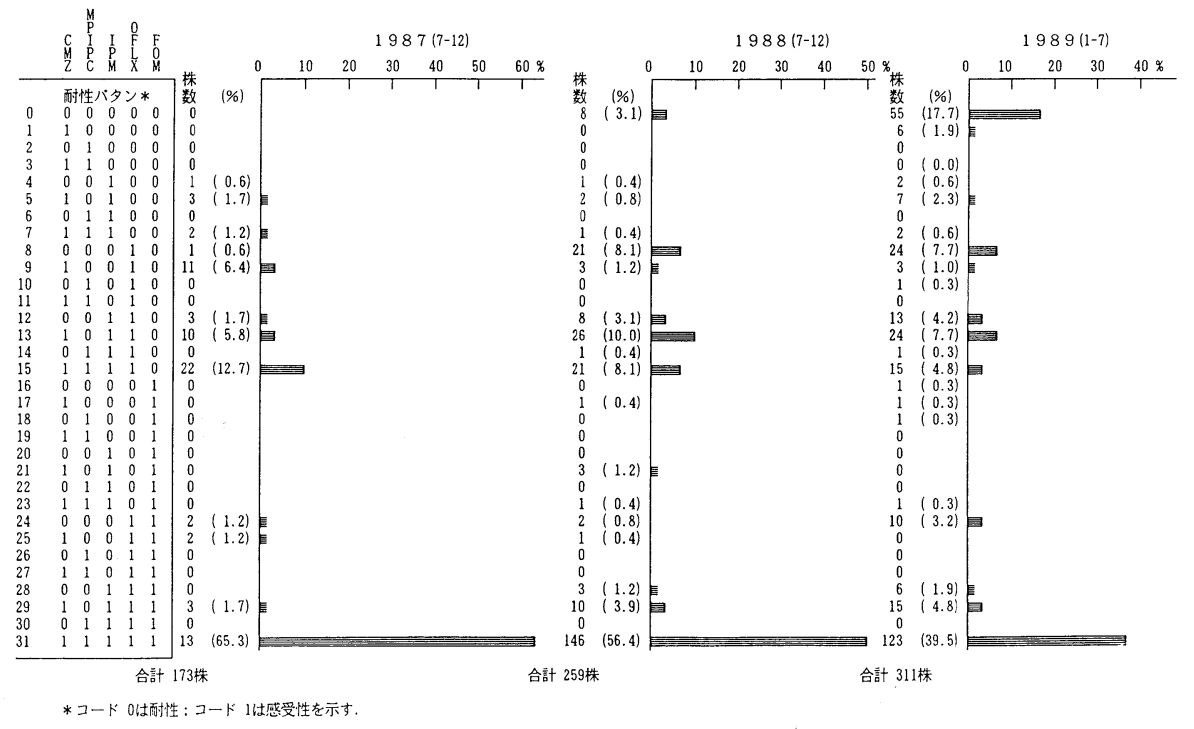

図３黄色ブ菌の年次別「耐性パタン」分布 


\section{MRSA の多剤而性の検定}

図 1 に見られるように，1987年以降 $\beta$ ラタム剤 やピリドンカルボン酸剤などの有効率が急速に減少 している.このことは耐性菌の多くが浪同時に「多 鼡耐性」を獲得したことを示唆する。

黄色ブ菌による感染症でよく用いられる $\beta$ ラタ ム剤，CMZ，MPIPC，IPM および作用機作の異な る OFLX と FOMの 5 剂に関する「耐性パターン」 $\left(2^{5}=32\right.$ 種存在する) の年次別分布を図 3 に示し た。ここに見られるように，5凰耐性菌（パターン コード00000）は1987年までには検出されなかった が，1988年に $3 \%$ 発生し，1989年には $18 \%$ に増加し た。これと逆に，5鼡すべてに感受性を示す菌(コー ド11111)は1987年には65\%存在したが，1989年には 40\%に減少している.

また，職員キャリヤーの存在も指摘されており， 常時医療スタッフ自身の清潔を保持することが強く 望まれる。

\section{考察}

1. MRSA およびセフェム剂耐性黄色ブ菌の発生 要因

MRASA の報告はわずかに1960年代始めに見ら れていたが, 我が国では1970年代の後半から80年代 の始めにかけて検出頻度の上昇が種々の病院で見ら れるようになってきた。この時期はおもに緑膿菌を 目標に改良されたペニシリンや第二，第三世代セ フェム系薬剤の開発の時期と一致し, これらの薬剤 がかえってグラム陽性菌には効力が少ないことか ら, MRSA の慢延は主に第三世代セフェムの普及に よると考えられた。そのためセフェム剤にも最近は ブ菌にも効く flomoxef や cefzonam などが開発さ れ，第一世代のセフェム剤も併用薬剤として見直さ れている.

ブ菌の $\beta$ ラタム耐性は, 始めは PC 系薬剤を不 活性化する PCase 産生によるもので, これは主にプ ラスミド上の遺伝子により支配され, 導入等で菌株 間を伝播もしうるので，ほとんど菌株が PC 耐性に なった. しかしその後 PCase に不活化されない PCp セフェムが開発されるに及んで, 菌はそれ自身 の PC 作用点である細胞壁合成酵素 (PBP) をかえ ることによって適応してきた。つまり必須酵素 PBP 2の代わりにPBP 2を新しく産生することによる 耐性化である ${ }^{4}$.殁どの $\beta$ ラクタム郕の多用が PBP 2 ,
の産生を促し, 早晚耐性菌の増加蔓延に至るものと 考えられる。

この他，不十分な無菌操作による耐性菌の患者間 伝播も耐性菌増加の原因であり，本報のように人の 移動の多い外科系診療科や，患者が集まるNo.20の 科など, 耐性菌の多い結果となると考えられる.

細菌検查を行う立場からは：

(1)「漫然とした」抗菌剤選択をせず，細菌検査報告 書に「高度感受性」(判定基準 3 ) を示すセフェム剤 があった場合はそれらを使用し, 判定基準 2 のセ フェム剤の使用はさけるべきべある。なぜなら, 判 定基準 2 (中等度感受性) を示した菌株は，既に「 $\beta$

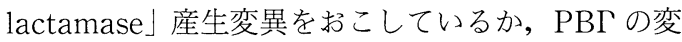
異を抗こしている可能性があるからである.

(2)判定基準 3 を示すセフェム剤が無い場合は判定基 準 3 を示す他剤(FOM, MINO, CP, NFLX, OFLX など）の使用を試みることも必要と考えられる。

少なくとも，群大病院に於いては，1989年現在， 黄色ブ菌の $98 \%$ MINO または, CP に感受性を示 しているので，これらの薬剤のもつ肝障害や貧血等 の副作用にも注意をしながら MINO または PC を 試みるのも一つの方法と考える。

これらの他，EM，LCM などの古典的な抗ブ菌剤 も他剂耐性 MRSA の40\%程度には有効である。検 查結果を参考にして，これらの「忘れられていた」 古い抗菌剤を上手に使うことも重要であると考えら れる.

(3)ある抗菌剤が無効であった場合, 次の抗菌剤を選 択する場合，抗菌作用機作の異なる（したがって耐 性獲得機作も異なる）薬郕を選ぶべきであることは 言うまでもない.

(4)病室管理および無菌操作の留意

黄色ブ菌感染症のみならず，すべての感染症につ いて当てはまることだが, 無菌操作に習熟して患者 から患者へ病原菌の院内伝播を防ぐことが基本であ る。

日和見感染の予防には「妙手」はなく，オーソドッ クスな「病室管理」によって耐性菌の病棟内伝播を 防止する以外にない.

$$
\text { 総括 }
$$

1977年から1989年（7月）までの13年間において 群大病院中央検査部で分離された黄色ブ菌の薬剤耐 性菌の発生状況，特に $\beta$ ラク 剂耐性菌の発生状 
況について述べた.

当院における MRSA の発生は1987年までは比較 的低率で, 分離黄色ブ菌の $10 \%$ 程度に止まっていた が，1988年以降急増し，1989年前期では分離ブ菌の $50 \%$ を越えるに至った。特に外科系の科で分離頻度 が高い.このままの傾向が続けば，今後数年も待た ずに黄色ブ菌感染症に対してすべての $\beta$ ラタム剤 が無効になることも予測される．さらに著名な事実 は MRSA の多剤耐性化であり，5薬剤についての 而性株で調べると，1989年では，耐性菌の中では 5 薬剤すべてに耐性のものが18\%で最も多かった.

\section{謝辞}

稿を終えるにあたり御校閲頂いた群馬大学医学部微生 物学教室橋本一教授に深甚なる謝意を表します。また終 始御協力を賜った群馬大学医学部附属薬剂而性菌実験施 設井上松久助教授に御礼申し上げます。

\section{文献}

1) Wenzel, R.P.: The emergence of Methicillin-resistant Staphlococcus aureus. Ann Int Med. 97, 440-442, 1982.

2）瀬川博子：市中感染もでる MRSA 。交差耐 性獲得が進み治療に限界, NIKKEI MEDICAL 1989年 5 月号, pp80-84.

3）財医療情報開発センター： 薬剤感受性情報 (1986).

4）横田 健・松本慶蔵：MRSA 感染症. ライフ サイエンス社刊 1986.

5) 三橋 進・松本慶蔵編：化学療法と感染症学 会出版センター刊 1986 .

6）田波 洋：臨床分離株の薬剂感受性の現在 值. 診療と新薬，21，2167-2484，1985.

7) 田波 洋, 他：群馬大学医学部附属病院にお ける臨床分離菌の変遷. 化学療法の領域, 13, 1698-1706, 1987.

8）橋本 一, 他：耐性が問題の細菌類. 日本臨床, 42, 158-163, 1984. 


\title{
STUDIES ON THE ISOLATION AND YEARLY CHANGES OF METHICILLIN-RESISTANT S. AUREUS AT GUNMA UNIVERSITY HOSPITAL
}

\author{
AYAKO TAKAHASHI, SACHIE YOMODA, TETUO MACHIDA, \\ YUKIHITO FUKUMURA, ISAO KOBAYASHI, HISAO KUMAKURA* \\ NORIHIRO KATO*, TOHRU HORIKOSHI**, YOH TANAMI*** \\ Department of Laboratory Medicine and \\ Clinical Laboratory Center, Gunma University School of Medicine Maebashi 371, Japan \\ (Director and Chairman: Pro. I.KOBAYASHI) \\ *Second Department of Internal Medicine, \\ Gunma University Shcool of Medicine, \\ ${ }^{* *}$ Department of Neurosurgery, Yamanashi Medical College \\ ${ }^{* * *}$ Shinohara Hospital
}

A 13-years survey on drug-resistant S.aureus isolated in the microbiological section of the Clinical Laboratory Center of Gunma University Hospital from 1977 to 1989 is summarized. The frequency of methicillin-resistant S.aureus (MRSA) was less than 10\% untill 1987, but it began to increase greatly after 1988 . More than $50 \%$ of S.aureus isolated in 1989 were MRSA. MRSA were common in inpatients, particularly those in the surgical departments. Another feature of MRSA isolated in recent yearn is their tendensy to be resistant to multiple drugs: $18 \%$ of MRSA isolated in 1989 were resistant to 5 drugs.

Key words: Methicillin-resistant S.aureus (MRSA) 